\title{
STRUCTURE OF VOCATIONAL INTERESTS IN MACEDONIA AND CROATIA - EVALUATION OF THE SPHERICAL MODEL
}

UDC 159.9.072:331.54(497.17+497.13)

\author{
Vladimir Hedrih $^{1}$, Iva Šverko ${ }^{2}$, Ivana Pedović ${ }^{1}$ \\ ${ }^{1}$ University of Niš, Faculty of Philosophy, Department of Psychology, Serbia \\ ${ }^{2}$ Institute of Social Sciences "Ivo Pilar", Zagreb, Croatia
}

\begin{abstract}
The goal of the current paper was to explore the construct validity of the spherical and the hexagonal models of vocational interests by exploring the extent to which these models fit the data obtained on samples of Macedonian and Croatian university students. Croatian and Macedonian versions of the Personal Globe Inventory (PGI) were administered to a sample of 1367 student of various faculties in Croatia and Macedonia (737 participants from the Republic of Macedonia and 630 from Croatia). Results showed that the spherical and hexagonal models fit the data better than chance, and that these models explain substantial proportions of variance of vocational interest measures. Exploration of the factor structure of the obtained measures of vocational interest on the studied samples showed that the obtained structure generally corresponds to theoretical propositions. The obtained dimensions correspond to the latent space defined by Prediger's dimensions and the dimensions of Prestige of the spherical model.
\end{abstract}

Key words: vocational interests, spherical model, Holland's model, PGI, RIASEC.

\section{INTRODUCTION}

One of the main lines of research in the area of vocational interests is aimed at the creation of a comprehensive taxonomy of vocational interests. Probably the most wellknown model in this area is the famous hexagonal model of vocational interest proposed by John Holland (Holland 1959, 1994), which includes six types of vocational interests that stand in a circumplex interrelation, named Realistic (R), Investigative (I), Artistic (A), Social (S), Enterprising (E) and Conventional (C). These are spatially represented as points at the bases of an equally-sided hexagon.

Received November 25, 2017 / Accepted May 22, 2018

Corresponding author: Vladimir Hedrih

University of Niš, Faculty of Philosophy, Ćirila i Metodija 2, 18000 Niš, Serbia

E-mail: vladimir.hedrih@filfak.ni.ac.rs 
Holland's hexagon, like any hexagon, is a two-dimensional figure which therefore exists in a two-dimensional space. The meaning of the two dimensions defining this space was specified by Prediger (Prediger 1982, 1998; Prediger \& Swaney 2004), who named them People-Things and Ideas-Data. The first of the two dimensions is placed so that it passes through the positions of $\mathrm{R}$ and $\mathrm{S}$ types on the hexagon. It defines the preference for working with people that is opposed to the preference for working with things. The second dimension stands orthogonal to the first dimension and passes between I and A types on one side of the hexagon, and $\mathrm{C}$ and $\mathrm{E}$ types on the other. It defines the preference for working with ideas as opposed to the preference for working with data. Apart from the Prediger's model, two other prominent definitions of the two dimensions exist. These definitions are rotations of Prediger's dimensions. One of them was proposed by Hogan in 1983 (Rounds \& Tracey 1993) and in it the Prediger dimensions are rotated 30 degrees, thus creating the dimensions of conformism and sociability, which their author proposed correspond to dimensions of the Big Five model. The Conformism dimension passes through A and $\mathrm{C}$ types, while the Sociability dimension passes between $\mathrm{S}$ and $\mathrm{E}$ type positions on one side of the hexagon and between $\mathrm{R}$ and $\mathrm{I}$ types on the other. Rounds and Tracey (Rounds \& Tracey 1993) rotated the Prediger dimensions by 60 degrees and obtained two dimensions that they did not name. Of these dimensions, one passes through I and E, and the other, orthogonal to it, passes through A and $\mathrm{S}$ on one side, and through $\mathrm{R}$ and $\mathrm{C}$ on the other.

When conducting component analysis, these dimensions are typically extracted after the so-called general factor - the first extracted factor, typically having high saturations on all vocational interest types. As a possible method for the explanation of the existence of the general factor, authors mention situational framing during the process of responding, which happens due to the way questions are asked and the uniform format of the response scale and a stable response style, like acquiescence or proneness for giving socially desirable responses. As possible substantial explanation for the general factor phenomenon, stable personality traits independent of the testing situation (such as enthusiasm, optimism and general broadness of interests) are listed. And while there is some debate about the exact nature of this factor, authors agree that it is not a dimension of vocational interests and should not be interpreted as such (Darcy \& Tracey 2003; Hedrih 2008; Šverko \& Babarović 2016).

Holland's model has so far been a subject of a large number of studies that primarily checked its so-called structural validity, i.e. checked its construct validity by conducting studies of internal structure. These studies examined if the circumplex relation between the six vocational interest types that is proposed by Holland's theory fits the empirically obtained data. But, the results obtained varied greatly across countries. While studies conducted in Japan, Israel, Iceland, Croatia, USA and Serbia uniformly showed a high level of fit of empirical data to theoretical expectations (Einarsdóttir, Rounds, Aegisdóttir, \& Gerstein 2002; Hedrih \& Šverko 2007; Hedrih 2006; Rounds \& Tracey 1996; Šverko 2002; Šverko \& Babarović 2006; Šverko \& Hedrih 2010), the same was not the case in many other countries including some special samples from the US population (Elosua 2007; Farh, Leong, \& Law 1998; Leong et al. 1998; Long, Adams \& Tracey 2005; Rounds \& Tracey 1996; Ryan, Tracey \& Rounds 1996; Tak 2004; Morgan \& De Bruin 2018; Rounds \& Tracey 1993). Thus, exploring cross-population validity of the model, i.e. determining which populations the model fits and which it does not, became an important aspect of research on the topic. 
Taking all this and also some newer findings on the properties of relations between types of vocational interests into account, Tracey proposed a new, three-dimensional model of vocational interests (Tracey \& Rounds 1996; Tracey 2002). This model, apart from Prediger's two dimensions People-Things and Ideas-Data included a third dimension that Tracey named Prestige. This dimension defines the preference of a person for longer schooling, taking on tasks with a greater level of responsibility and duties and engaging in more prestigious vocations. This model proposes the existence of 18 types of interests distributed in the form of a sphere in three dimensions. For this reason, this model is called the spherical model of vocational interests (Figure 1 and 2). Eight vocational interest types are located at the equator of the sphere i.e. at its middle level, that is sometimes referred to as Holland's plane or Holland' equator. These cover the same area as Holland's types, and therefore Holland's types can easily be calculated from eight spherical interest types. This makes the spherical model of vocational interests more encompassing and more precise than Holland's. Unlike the case of Holland's model, validation studies so far have tended to produce relatively uniform and confirming results (Hedrih 2008; Long et al. 2005; Maria \& Darcy 2005; Šverko 2008; Tracey 2002; Tracey \& Rounds 1996; Tracey, Watanabe, \& Schneider 1997).

Considering the relationship between the hexagonal and the spherical model, as both are topics of the current study, it should be said that although coming from different authors, these are not two competing models of vocational interests, but rather two models of different width describing the same latent space. Holland's hexagonal model is included in the spherical model and it covers the equatorial plane of the spherical model. The difference is that the hexagonal model partitions this plane into six types, while the authors of the spherical model prefer the partition of this plane into 8 interest types, which they call the Basic interest types. It should be noted that three of these types are identical between the hexagonal model and the Basic interest types of the spherical model, although they have different names. These three equivalent types are Realistic (R) / Mechanical, Investigative (I) / Nature-outdoors and Artistic (A). Given the fact that this partition into types is arbitrary and the product of convenience as demonstrated by Tracey \& Rounds (Tracey \& Rounds 1995), rather than a reflection of naturally existing categories, the two partitions of the vocational interest equator, i.e. the basic interest plane, can be considered equivalent. Also, comparisons of the fit of the data to the RIASEC hexagon and to Tracey's basic interest types octagon typically yield similar levels of fit to the data of both models (e.g. Hedrih 2008).

Research studies conducted in the region of South-East Europe (Croatia, Serbia, Bulgaria) so far have confirmed both the validity of the hexagonal and the spherical models and that their structures are almost identical, especially between Serbia and Croatia (Hedrih 2008; Hedrih, Stošić, Simić, \& Ilieva 2016; Šverko 2008b). On the other hand, review of the literature yielded no data on the functioning of these theoretical models in the Republic of Macedonia, or of Macedonian versions of these instruments, so the results of this study would be of particular use to practitioners and researchers working in Macedonia in the areas that include assessment of vocational interests and career counselling in general.

The goal of the current paper was to explore the construct validity of the spherical and the hexagonal models of vocational interests by exploring the extent to which these models fit the data obtained on samples of Macedonian and Croatian students. 
SPHERICAL MODEL OF VOCATIONAL INTERESTS

UPPER HEMISPHERE

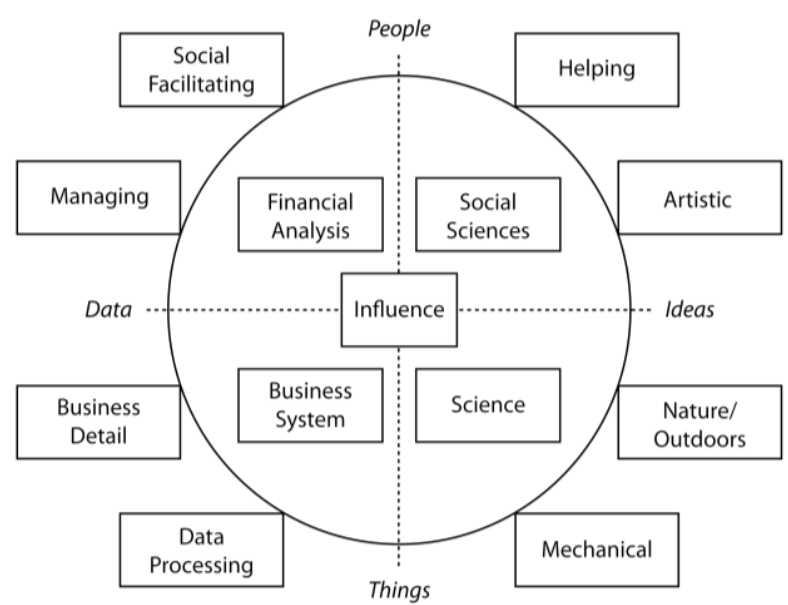

Fig. 1 Spherical model of vocational interests - upper hemisphere, horizontal cross-section at the level of the Holland equatorial plane. Vocational interest types at the equator are presented outside the circle. Their position on the spherical model roughly corresponds to the intersection between their rectangle and the circle. Inside the circle are upper prestige vocational interests. Their positions inside the sphere approximately correspond to their positions in the model. Created according to: Tracey 2002.

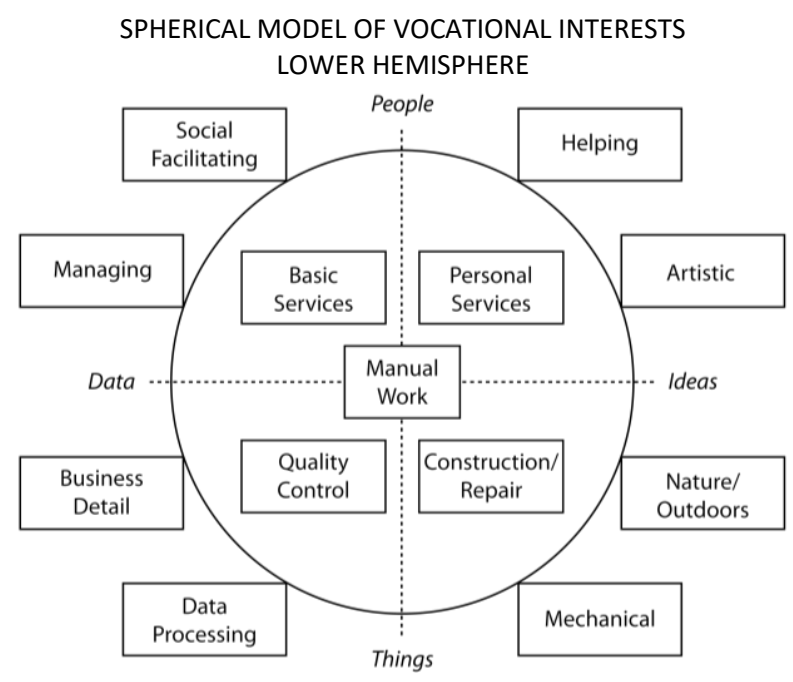

Fig. 2 Spherical model of vocational interests - lower hemisphere, horizontal cross-section at the level of the Holland equatorial plane. Vocational interest types at the equator are presented outside the circle. Their position on the spherical model roughly corresponds to the intersection between their rectangle and the circle. Inside the circle are lower prestige vocational interests. Their positions inside the sphere approximately correspond to their positions in the model. Created according to: Tracey 2002. 


\section{METHODS}

\subsection{Sample of participants}

The sample consisted of 1367 university students of various faculties in the Republic of Macedonia and the Republic of Croatia. Of this number 737 (77.3\% female, $22.7 \%$ male) participants were from the Republic of Macedonia and 630 (59.4\% female, $40.6 \%$ male) from Croatia. Average age of the participants in the Macedonian part of the sample was around 21.2 years, and in the Croatian part of the sample was 23.6 years. The age of participants ranged between 19 and 40, with most of the participants between 20 and 22 in the Macedonian part of the sample, and 22 and 24 in the Croatian part of the sample. According to their study program, participants from the Croatian part of the sample are preparing to become psychologists $(15.1 \%)$, recreation workers and sport trainers $(11.1 \%)$, economists $(10.1 \%)$, mechanical engineers $(9.0 \%)$, architects $(5.7 \%)$, art historians $(5.2 \%)$, philologists $(4.7 \%)$, wood technology engineers $(4.4 \%)$, medical doctors $(4.3 \%)$, textile technology engineers $(4.1 \%)$, rehabilitation counselors $(3.9 \%)$, electrical and electronic engineers $(3.6 \%)$, forestry engineers $(3.6 \%)$, computer programmers $(2.0 \%)$, civil engineers $(1.6 \%)$, lawyers $(6.1 \%)$, mathematicians $(1.6 \%)$, and art teachers $(1.3 \%)$. The sample also included students preparing for various other professions with smaller frequencies. The Macedonian part of the sample consisted of students preparing to become social workers $(16,7 \%)$, psychologists $(16,0 \%)$, defectologists $(8,9 \%)$, educationalists/pedagogues $(8,3 \%)$, economists, bankers, managers and marketing managers $(8,2 \%)$, foreign language philologists $(8,2 \%)$, molecular biologists, biologists, biochemists, physicists, mathematicians, mathematical physicists, applied physicists (8\%), geography teachers $(3,6 \%)$, music theorists, solo singers and other professions in the area of music $(3,5 \%)$, software engineers $(2,7 \%)$, defense analysts $(2,4 \%)$ and various other professions with smaller frequencies (graphic, interior, fashion, designers, dentists, translators, internet and mobile technology engineers, etc.).

\subsection{Instruments}

For collecting data on vocational interests, the Croatian and Macedonian versions of the Personal Globe Inventory were used (PGI, Tracey 2002; Croatian version - Šverko 2008). The Macedonian version of PGI was created by the authors of the current study, through the process of backtranslation. In the process, two items from the original were replaced, as vocations mentioned in them are generally not familiar in Macedonia. The replacements used were the same ones as in the Croatian version. "Ride attendant" was replaced with "taxi driver" and "personal shopper" was replaced with "personal caregiver".

The PGI inventory of vocational interests consists of 324 items representing various measures of vocational interests proposed by the model. The first 108 items represent various activities. The participant is required to answer questions about each item - to assess his own preference for the activity described in the item and to also assess his own competencies for conducting the described activity. The participant gives both responses by using a seven-point scale (1-Strongly dislike, unable to do to 7-Strongly like, Very competent). The other 108 items represent various occupations, and the participant is required to specify their preferences for each of them, also by using a seven-point scale (1Strongly dislike, 7-Strongly like). For example, item number 2, indicator of the Managing type, asks the participant to what extent he/she would like to "Manage the running of a 
hotel". For this item, the participant is to specify how much he/she likes that activity, and then how competent for this activity he/she finds him/herself to be. In the third part of PGI, item 42 indicator of the same type asks the participant to how much he/she would like to be a "Hotel manager".

As a result, PGI delivers measures of six of Holland's types of vocational interests and 18 types of vocational interests proposed by Tracey's spherical model. It can also provide other measures based on alternative typologies of vocational interests, and of the three dimensions, but these were not used in the current study. Types of vocational interests measured by PGI are listed in table 1.

\subsection{Data collection procedure}

In both countries, students were asked to complete PGI during their regular classes. This was done in cooperation with the teachers and the faculty management. While the students filled in the PGI, at least one member of the research team was present, along with the professor or the assistant during whose class the data collection was conducted. The data collection procedure was anonymous, in the sense that no identifying data was required from the participants. On the other hand, as a form of incentive for participation, participants were offered feedback on their results, but to receive it they needed to enter their email address and name, thus forfeiting anonymity.

\subsection{Analyses}

Similarities between models and data was tested by using the randomization test of hypothetical orders, Myors's test, and multidimensional scaling. Correspondence between the theoretical model and data was also tested using principal component analyses.

Randomization $\mathrm{p}$ value is the level of statistical significance of the fit of model to the data, as it is used to test the null hypothesis that random permutation of rows and columns of the tested intercorrelation matrix fit the model as well as the empirically obtained intercorrelation matrix. For this reason, randomization $\mathrm{p}$ value smaller than .05 is interpreted as a confirmation that the tested theoretical model fits the data better than chance. The Correspondence Index (CI) is a descriptive measure of fit between the tested model and data ranging from -1 (no predictions were confirmed) to 1 (all predictions were confirmed). It is calculated by subtracting the proportion of the total number of predictions based on the tested model that were not confirmed, from the proportion of the total number of predictions based on the tested model that were confirmed. Both of these statistics were calculated using the RANDALL software package (Tracey 1997).

Myors's test calculates Spearman correlation coefficients between intercorrelations of types and ranks of expected correlation sizes according to theoretical models and thus higher values indicate a higher level of similarity between the tested model and data. Minimum percentage of variance explained for the RIASEC model was read from the table in the paper describing the method (Myors 1996), based on the obtained Spearman correlation. As these concrete values were not provided for the spherical model, they were calculated by the authors by extrapolating the method proposed by Myors to the 18type model. Spearman correlation between expected and obtained correlations sizes between the 18 types, and the value of a correlation coefficient statistically significant on the .05 level given the number of comparisons for the 18-type model were both converted to Fisher's $\mathrm{z}$. The second Fisher's $\mathrm{z}$ value was then subtracted from the first one. The 
result was converted back to a correlation coefficient, and squared, thus obtaining the minimum proportion of variance explained by the model value.

Fit of the theoretical model to the data by using multidimensional scaling was assessed by using the normalized raw stress coefficient and the stress- 1 coefficient. Both of these coefficients represent discrepancy between the data and the model, so that larger numbers represent larger levels of discrepancy, while values closer to zero indicate a greater fit of model to the data. The procedure of multidimensional scaling with fixed coordinates was used by supplying the final coordinate matrices corresponding to theoretical positions of types according to the tested model. For the RIASEC types, coordinates were organized so as to form a hexagon in two dimensions, while for the spherical model, coordinates provided formed an 18-point sphere-like body in threedimensional space. The number of dimensions of the final spatial solution was set to two for the RIASEC model and to three when the spherical model was tested. Coordinate matrices used for fixing final coordinates in these analyses are given in table 1 .

Table 1 List of types of the spherical and the hexagonal models with their coordinates used in the process of multidimensional scaling with fixed coordinates. Coordinates based on their theoretical positions.

\begin{tabular}{lrrrlrr}
\hline \multicolumn{3}{c}{ Tracey's spherical model } & \multicolumn{3}{c}{ Holland's hexagonal model } \\
\hline Dimensions $\rightarrow$ & $\begin{array}{c}\text { People- } \\
\text { things }\end{array}$ & $\begin{array}{r}\text { Ideas- } \\
\text { Data }\end{array}$ & Prestige & Dimensions $\rightarrow$ & $\begin{array}{r}\text { People- } \\
\text { Things }\end{array}$ & $\begin{array}{r}\text { Ideas- } \\
\text { Data }\end{array}$ \\
\hline Social Facilitating & -.383 & .924 & .000 & R - Realistic & -4.00 & .00 \\
Managing & -.924 & .383 & .000 & I - Investigative & -2.00 & 3.40 \\
Business Detail & -.924 & -.383 & .000 & A - Artistic & 2.00 & 3.40 \\
Data Processing & -.383 & -.924 & .000 & S - Social & 4.00 & .00 \\
Mechanical & .383 & -.924 & .000 & E - Enterprising & 2.00 & -3.40 \\
Nature/Outdoors & .924 & -.383 & .000 & C - Conventional & -2.00 & -3.40 \\
Artistic & .924 & .383 & .000 & & & \\
Helping & .383 & .924 & .000 & & & \\
Social Sciences & .522 & .522 & .710 & & & \\
Influence & .000 & .000 & 1.000 & & & \\
Business Systems & -.522 & -.522 & .710 & & & \\
Financial Analysis & -.522 & .522 & .710 & & & \\
Science & .522 & -.522 & .710 & & & \\
Quality Control & -.522 & -.522 & -.710 & & & \\
Manual Work & .000 & .000 & -1.000 & & & \\
Personal Services & .522 & .522 & -.710 & & & \\
Construction/Repair & .522 & -.522 & -.710 & & & \\
Basic Services & -.522 & .522 & -.710 & & & \\
\hline
\end{tabular}

Tucker's coefficients of congruence were used to assess the similarity of component structures obtained on the two samples. These were calculated using a custom created script for calculating these statistics. It is calculated by dividing the sum of products of corresponding loadings with the square root of product of sums of squared loadings from the two factor loading matrices. It ranges from -1 to 1 , with the absolute value of .80 being considered a minimum threshold for factor similarity (Fulgosi 1988), absolute 
values between .85 and .94 indicating fair level of factor similarity, and values above .95 indicating the factors are virtually identical (Lorenzo-Seva \& ten Berge 2006).

According to the theory, apart from the three fundamental dimensions underlying the spherical model or two underlying the hexagonal model, there also exists a general factor at the base of the vocational interest types. The meaning of this factor is not substantial, i.e. it is not a dimension of vocational interests itself, but it masks the circular and spherical structures of the other factors/components if factor rotation is applied to the obtained factor solution. For this reason, principal component analyses were conducted without rotation, in order to prevent the saturation of the fundamental dimensions with variance which does not represent the substance of vocational interests, as suggested by Tracey (2000).

\section{RESULTS}

\subsection{Fit of the data to the spherical and hexagonal models}

Fit of the hexagonal and the spherical model to the data was tested by using multidimensional scaling with fixed coordinates, a randomization test of hypothetical orders, and Myors's test. The obtained results are shown in tables 2 and 3. Apart from the country samples as a whole, analyses were conducted on male and female subsamples separately and their values are presented in the brackets below the results obtained on country samples

Table 2 Fit of the propositions of the spherical model to the empirical structure of the data: randomization test of hypothetical orders, Myors's test, and multidimensional scaling.

\begin{tabular}{|c|c|c|c|}
\hline Test & Parameter & $\begin{array}{c}\text { Macedonia } \\
\text { (Male/Female) }\end{array}$ & $\begin{array}{c}\text { Croatia } \\
\text { (Male/Female) }\end{array}$ \\
\hline \multirow{2}{*}{$\begin{array}{l}\text { MDS with fixed } \\
\text { coordinates }\end{array}$} & Normalized raw Stress & $\begin{array}{c}.06 \\
(.09 / .14)\end{array}$ & $\begin{array}{c}.05 \\
(.09 / .13)\end{array}$ \\
\hline & Stress-1 & $\begin{array}{c}.25 \\
(.30 / .37)\end{array}$ & $\begin{array}{c}.23 \\
(.31 / .35)\end{array}$ \\
\hline \multirow{2}{*}{$\begin{array}{l}\text { Randomization test of } \\
\text { hypothetical orders }\end{array}$} & $\begin{array}{c}\text { Randomization } \\
p \text { value - significance }\end{array}$ & $\begin{array}{c}.001 \\
(.001 / .001) \\
\end{array}$ & $\begin{array}{c}.001 \\
(.001 / .001)\end{array}$ \\
\hline & Correspondence coefficient $(C I)$ & $\begin{array}{c}.55 \\
(.55 / .53) \\
\end{array}$ & $\begin{array}{c}.59 \\
(.58 / .62) \\
\end{array}$ \\
\hline \multirow{2}{*}{ Myors's test } & Correlation coefficient & $\begin{array}{c}.65 \\
(.65 / .63)\end{array}$ & $\begin{array}{c}.69 \\
(.68 / .72)\end{array}$ \\
\hline & $\begin{array}{c}\text { Min. } \% \text { of variance explained } \\
\text { by the model }\end{array}$ & $\begin{array}{c}32 \% \\
(32 \% / 30 \%)\end{array}$ & $\begin{array}{c}38 \% \\
(36 \% / 42 \%)\end{array}$ \\
\hline $\begin{array}{l}\text { Concordance of } \\
\text { correlation matrices }\end{array}$ & $\begin{array}{c}\text { Spearman correlation coefficient } \\
\text { (Croatia-Macedonia) }\end{array}$ & \multicolumn{2}{|c|}{.945} \\
\hline
\end{tabular}


Table 3 Fit of the propositions of the Holland's hexagonal model to the empirical structure of the data: randomization test of hypothetical orders, Myors's test, and multidimensional scaling.

\begin{tabular}{|c|c|c|c|}
\hline Test & Parameter & $\begin{array}{c}\text { Macedonia } \\
\text { (Male/Female) }\end{array}$ & $\begin{array}{c}\text { Croatia } \\
\text { (Male/Female) }\end{array}$ \\
\hline \multirow{2}{*}{$\begin{array}{l}\text { MDS with fixed } \\
\text { coordinates }\end{array}$} & Normalized raw Stress & $\begin{array}{c}.04 \\
(.04 / .05)\end{array}$ & $\begin{array}{c}.04 \\
(.05 / .06)\end{array}$ \\
\hline & Stress-1 & $\begin{array}{c}.19 \\
(.19 / .22)\end{array}$ & $\begin{array}{c}.21 \\
(.23 / .24)\end{array}$ \\
\hline \multirow{3}{*}{$\begin{array}{l}\text { Randomization test } \\
\text { of hypothetical orders }\end{array}$} & Randomization & .017 & .017 \\
\hline & $p$ value - significance & $(.017 / .017)$ & $(.017 / .017)$ \\
\hline & Correspondence coefficient $(C I)$ & $\begin{array}{c}.96 \\
(.92 / .89)\end{array}$ & $\begin{array}{c}.89 \\
(.72 / .92)\end{array}$ \\
\hline \multirow{2}{*}{ Myors's test } & Correlation coefficient & $\begin{array}{c}.91 \\
(88 / 86)\end{array}$ & $\begin{array}{c}.86 \\
(74 / 88)\end{array}$ \\
\hline & $\begin{array}{c}\text { Min. } \% \text { of variance explained } \\
\text { by the model }\end{array}$ & $\begin{array}{c}60 \% \\
(50 \% / 45 \%)\end{array}$ & $\begin{array}{c}45 \% \\
(20 \% / 50 \%)\end{array}$ \\
\hline $\begin{array}{l}\text { Concordance of } \\
\text { correlation matrices }\end{array}$ & $\begin{array}{l}\text { Spearman correlation coefficient } \\
\text { (Croatia-Macedonia) }\end{array}$ & \multicolumn{2}{|c|}{.959} \\
\hline
\end{tabular}

As for Tracey's spherical model, the results show that empirical data in both samples fits the propositions of the tested model better than chance - both the randomization test of hypothetical orders and Myors's test are statistically significant on both samples. Other data also point to the conclusion that the model explains a substantial and similar percent of variance of relations between types on both samples. Indicators of fit of the data from the Macedonian sample to the model are numerically lower than on the Croatian sample, but this difference is small. When the results of these tests on subsamples by gender are considered, we can see that results for the two genders are also similar, the exception being the results of MDS which shows much higher discrepancy of the gender subsamples than of the integrated samples by country.

Considering the hexagonal model, results show that data fits the model better than chance and also indicate a substantial percentage of the data variance being explained by the model. Unlike the case of the spherical model, fit indicators are numerically somewhat higher on the Macedonian sample in this case. However, a randomization test of differences in fit of the two samples to the data showed that the difference in fit is not statistically significant. This conclusion is also supported by the fact that there is a high similarity between vocational type measures intercorrelation matrices on the two samples. Considering the results on subsamples by gender it can be seen that the results of the two genders are similar on the Macedonian sample, but that there is a noticeable difference in fit on the Croatian sample, with the data from the male subsample showing a much poorer fit to the model.

\subsection{Fundamental dimensions of vocational interests}

Results of the parallel analysis showed that there are four raw data factors that have higher eigenvalues than random data factors created in this procedure when the 18 Tracey's types are analyzed. The same procedure shows that there are three such factors when the six Holland's types are considered. The results of the principal component analysis show that in 
both samples the extracted factors explain substantial percentages of variance of both Tracey's and Holland's types, with the percentage of explained variance of Tracey's types being somewhat higher in the Croatian sample (tables 4 and 5).

Saturations and correlations with the theoretical dimensions indicate that there is a general factor underlying the structures of both Tracey's and Holland's types, and on which all interest scales have high saturations, while other factors generally correspond to Rounds and Tracey's dimensions and the dimensions of Prestige (Table 4 and 5). Tucker's coefficients of congruence indicated that the structure of dimensions is equal in both the Macedonian and Croatian samples, regardless of whether Tracey's or Holland's types are considered.

Table 4 Unrotated factor structure of Tracey's types of vocational interests: factor loadings, percentage of variance explained, factor similarities and correlations with theoretical dimensions

\begin{tabular}{|c|c|c|c|c|c|c|c|c|}
\hline & \multicolumn{4}{|c|}{ Macedonian sample } & \multicolumn{4}{|c|}{ Croatian sample } \\
\hline & $\mathrm{F} 1$ & $\mathrm{~F} 2$ & $\mathrm{~F} 3$ & $\mathrm{~F} 4$ & $\mathrm{~F} 1$ & $\mathrm{~F} 2$ & F3 & F4 \\
\hline Social Facilitating & 0.69 & 0.33 & 0.36 & -0.26 & 0.56 & 0.47 & -0.48 & -0.28 \\
\hline Managing & 0.66 & -0.20 & 0.54 & -0.17 & 0.66 & -0.12 & -0.59 & -0.21 \\
\hline Business Detail & 0.56 & -0.40 & 0.57 & 0.09 & 0.68 & -0.43 & -0.47 & 0.10 \\
\hline Data Processing & 0.61 & -0.43 & -0.15 & 0.22 & 0.64 & -0.50 & 0.20 & 0.26 \\
\hline Mechanical & 0.72 & -0.35 & -0.40 & 0.14 & 0.67 & -0.45 & 0.44 & 0.14 \\
\hline Nature/Outdoors & 0.64 & 0.31 & -0.43 & 0.30 & 0.46 & 0.48 & 0.47 & 0.33 \\
\hline Artistic & 0.49 & 0.49 & -0.25 & 0.15 & 0.20 & 0.66 & 0.25 & 0.17 \\
\hline Helping & 0.52 & 0.68 & 0.26 & -0.04 & 0.31 & 0.83 & -0.13 & -0.03 \\
\hline Social Sciences & 0.52 & 0.64 & 0.16 & 0.11 & 0.32 & 0.77 & -0.10 & 0.11 \\
\hline Influence & 0.77 & 0.21 & 0.16 & 0.34 & 0.63 & 0.42 & -0.15 & 0.43 \\
\hline Business Systems & 0.71 & -0.40 & 0.34 & 0.22 & 0.76 & -0.38 & -0.34 & 0.23 \\
\hline Quality Control & 0.81 & -0.37 & -0.05 & -0.12 & 0.81 & -0.34 & 0.24 & -0.20 \\
\hline Manual Work & 0.64 & -0.35 & -0.41 & -0.37 & 0.65 & -0.19 & 0.47 & -0.42 \\
\hline Personal Service & 0.60 & 0.47 & -0.03 & -0.38 & 0.51 & 0.60 & 0.04 & -0.38 \\
\hline Financial Analysis & 0.44 & -0.31 & 0.45 & 0.21 & 0.67 & -0.38 & -0.48 & 0.21 \\
\hline Science & 0.64 & 0.24 & -0.38 & 0.43 & 0.54 & 0.41 & 0.29 & $\mathbf{0 . 5 0}$ \\
\hline Construction/Repair & 0.63 & -0.41 & -0.47 & -0.24 & 0.62 & -0.33 & 0.55 & -0.25 \\
\hline Basic Service & 0.73 & 0.19 & -0.09 & -0.49 & 0.61 & 0.37 & 0.04 & -0.54 \\
\hline$\%$ variance explained & 41.0 & 16.0 & 11.9 & 7.10 & 35.2 & 23.4 & 13.10 & 9.00 \\
\hline total & \multicolumn{4}{|c|}{76.1} & \multicolumn{4}{|c|}{80.7} \\
\hline $\mathrm{CC}$ & .98 & .97 & -.98 & 1.00 & I & l & I & I \\
\hline People-things & -.06 & .79 & .41 & -.31 & -.20 & .82 & -.40 & -.27 \\
\hline Ideas-data & -.03 & .63 & -.68 & .20 & -.20 & .67 & .63 & .20 \\
\hline Sociability & -.04 & .35 & .80 & -.41 & -.09 & .44 & -.78 & -.39 \\
\hline Non-conformism & -.05 & .85 & -.39 & .03 & -.25 & .88 & .30 & .04 \\
\hline Dimension 1 & .00 & -.22 & .87 & -.34 & .09 & -.20 & -.87 & -.36 \\
\hline Dimension 2 & -.06 & .92 & -.03 & -.14 & -.25 & .93 & -.03 & -.12 \\
\hline Prestige & .26 & .28 & .51 & .73 & .10 & .33 & -.52 & .76 \\
\hline
\end{tabular}

Note. Correlations and saturations higher than .40 are given in bold. CC - Tucker's coefficients of congruence between matching factors from the two samples. 
Table 5 Unrotated factor structure of Holland's types of vocational interests: factor loadings, percentage of variance explained, factor similarities and correlations with theoretical dimensions.

\begin{tabular}{|c|c|c|c|c|c|c|}
\hline & \multicolumn{3}{|c|}{ Macedonian sample } & \multicolumn{3}{|c|}{ Croatian sample } \\
\hline & F1 & $\mathrm{F} 2$ & F3 & F1 & $\mathrm{F} 2$ & F3 \\
\hline $\mathrm{R}$ & .71 & -.49 & -.37 & .53 & .72 & -.32 \\
\hline I & .75 & .24 & -.46 & .71 & -.26 & -.50 \\
\hline A & .64 & .55 & -.30 & .56 & -.61 & -.34 \\
\hline$S$ & .67 & .48 & .45 & .63 & -.56 & .41 \\
\hline $\mathrm{E}$ & .70 & -.10 & .63 & .59 & .13 & .75 \\
\hline C & .67 & -.65 & .08 & .52 & .79 & .03 \\
\hline$\%$ variance explained & 47.9 & 21.0 & 17.4 & 35.4 & 31.9 & 19.9 \\
\hline total & & 86.3 & & & 87.2 & \\
\hline $\mathrm{CC}$ & 1.00 & -.99 & .99 & l & l & l \\
\hline People-things & -.01 & .85 & .52 & .04 & -.89 & .45 \\
\hline Ideas-data & .12 & .67 & -.69 & .17 & -.68 & -.69 \\
\hline Sociability & -.08 & .38 & .91 & -.06 & -.50 & .86 \\
\hline Non-conformism & .10 & .90 & -.35 & .15 & -.92 & -.33 \\
\hline Dimension 1 & -.12 & -.24 & .94 & -.15 & .17 & .96 \\
\hline Dimension 2 & .06 & .98 & .05 & .11 & -.98 & .05 \\
\hline Prestige & .28 & .15 & .20 & .23 & -.21 & .17 \\
\hline
\end{tabular}

Note. Correlations and saturations higher than .40 are given in bold. CC - Tucker's coefficients of congruence between matching factors from the two samples

When the results of the principal component analyses on subsamples by gender are considered, it can be seen that factor structures of gender subsamples are similar on the Macedonian sample, but that there is much smaller similarity between extracted factors on the gender subsamples in the Croatian sample. This observation stands for both the spherical and the RIASEC model. On the other hand, inspection of the structure of saturations shows that types opposing saturations are all in accordance with the theoretical models, meaning that types with the strongest saturations of opposite signs are always those on opposing sides of the theoretical models, both RIASEC and the spherical one. Relying to Fulgosi's (Fulgosi 1988) criteria of factor equivalence $(\mathrm{CCmin}=.80)$, in the Croatian samples only the third factor showed gender invariance $(\mathrm{CC}=.666)$. However, the distortion of saturations was obviously not too strong, since the third factors extracted from the two national samples still showed the equivalence $(\mathrm{CC}=.871$; Table 6$)$. 
Table 6 Unrotated factor structure of Tracey's types of vocational interests: factor loadings, percentage of variance explained, factor similarities on gender subsamples and correlations with theoretical dimensions of vocational interests.

\begin{tabular}{|c|c|c|c|c|c|c|c|c|}
\hline & \multicolumn{4}{|c|}{$\begin{array}{c}\text { Macedonian sample } \\
\text { (Male/Female loadings) }\end{array}$} & \multicolumn{4}{|c|}{$\begin{array}{c}\text { Croatian sample } \\
\text { (Male/Female loadings) }\end{array}$} \\
\hline & F1 & F2 & F3 & $\mathrm{F} 4$ & F1 & $\mathrm{F} 2$ & F3 & $\mathrm{F} 4$ \\
\hline ocis & $.78 / .71$ & $-.11 / .06$ & $.36 / .46$ & $-.21 /-.20$ & $.70 / .64$ & $.13 /-.06$ & $.33 / .61$ & \\
\hline Mar & $3 / .64$ & $-.45 /-.47$ & & & $6 / .63$ & $-.36 /$ & $.43 / .39$ & \\
\hline ess Detail & $.67 / .52$ & $-.57 /-.70$ & $.19 / .24$ & $.15 / .09$ & $.64 / .62$ & $-.54 /-.71$ & $.41 / .06$ & $.05 / .05$ \\
\hline rocessing & $.63 / .61$ & $-.25 /-.27$ & $-.35 /-.35$ & $.43 /$. & $.56 / .71$ & $-.46 /-$ & $-.18 /-.37$ & $.42 / .23$ \\
\hline Iech & $3 / .74$ & $-.03 /-.04$ & $-. .53 /-.47$ & $.24 /$. & $.65 / .74$ & $-.33 /$ & $-.47 /-.51$ & $.34 / .08$ \\
\hline ature/O & $.65 / .64$ & $.48 / .48$ & $-.15 / .-.22$ & $.35 / .29$ & .50 & $.56 / .56$ & $-.15 /-.34$ & $.36 / .26$ \\
\hline & $.50 / .52$ & $.49 / .51$ & $.07 /-.04$ & $.28 / .15$ & 33 & $.68 / .61$ & $.07 /-.11$ & $.21 / .13$ \\
\hline & $1 / .60$ & $.38 /$. & $.54 / .51$ & $-.08 /$ & 42 & $.71 /$ & $.13 / .56$ & -.12 \\
\hline & & $.46 /$. & $.58 /$ & -.12 & & $.65 /$ & & $.02 /$ \\
\hline & & $.22 /$. & $.42 /$ & & & $.35 /$ & & \\
\hline & $.71 / .70$ & $-.53 /-$ & $.14 /$. & $.17 /$ & & -.49 & & $.20 /$ \\
\hline ua & $.87 / .82$ & $-.20 /-$ & $-.15 /-$ & $-.04 /$ & & $-.34 /$ & $-.30 /$ & $-.06 /$ \\
\hline Ian & $.64 / .70$ & $.00 / .02$ & $-.56 /-.36$ & $-.31 /$ & & $-.10 /$ & $-.53 /-.24$ & $-.29 / .51$ \\
\hline e & $.72 / .63$ & $.29 / .38$ & $-.08 / .22$ & $-.41 /-.33$ & $.69 / .59$ & $.36 / .45$ & $-.15 / .26$ & $-.39 / .32$ \\
\hline & $.62 / .41$ & $-.60 /-.51$ & $.24 / .16$ & $.13 / .21$ & 61 & $-.49 /-.66$ & $.48 / .07$ & $.11 / .17$ \\
\hline & $.60 / .65$ & $.58 / .32$ & $-.10 /-.28$ & $.31 /$. & & $.42 / .36$ & $-.03 /-.28$ & $.50 /$ \\
\hline & $.69 / .68$ & $.09 /-$. & $-.59 /-.50$ & $-.24 /$ & & $-.23 /$ & $-.62 /$ & -.11 \\
\hline & $.79 / .72$ & $.07 /$. & $-.17 / .10$ & -.43 & & $.19 /$. & $-.12 / .23$ & $-.47 /$ \\
\hline$\%$ variance explained & & & $\begin{array}{c}12.74 / \\
9.89\end{array}$ & $\begin{array}{c}6.89 / \\
7.40\end{array}$ & & $\begin{array}{c}19.90 / \\
18.56\end{array}$ & $\begin{array}{c}10.11 / \\
11.61\end{array}$ & $\begin{array}{c}9.28 / \\
9.90\end{array}$ \\
\hline CC - genders* & $\begin{array}{l}.985 \\
(1-1)\end{array}$ & $\begin{array}{l}-.960 \\
(2-2)\end{array}$ & & $\begin{array}{l}.975 \\
(4-4)\end{array}$ & & $\begin{array}{l}.881 \\
(2-2)\end{array}$ & & \\
\hline CC -countries** & $\begin{array}{c}\text { Males } \\
.995 \\
(1-1)\end{array}$ & $\begin{array}{c}\text { Males } \\
.916 \\
(2-2)\end{array}$ & $\begin{array}{c}\text { Males } \\
.871 \\
(3-3)\end{array}$ & $\begin{array}{c}\text { Males } \\
.942 \\
(4-4)\end{array}$ & $\begin{array}{c}\text { Females } \\
.985 \\
(1-1)\end{array}$ & $\begin{array}{c}\text { Females } \\
-.960 \\
(2-2)\end{array}$ & $\begin{array}{c}\text { Females } \\
.963 \\
(3-3)\end{array}$ & $\begin{array}{c}\text { Females } \\
.975 \\
(4-4)\end{array}$ \\
\hline & $-.06 /-.02$ & $.29 /-.45$ & $.78 / .77$ & $-. .46 /-.24$ & $-.10 /-.15$ & $.69 / .39$ & $.42 / .84$ & $-.53 /-.14$ \\
\hline Ideas - Data & & $.90 /-.89$ & $-.21 /-.29$ & & & & $-.34 /-.29$ & $.29 / .18$ \\
\hline Sociability & & $-.25 / .21$ & $.78 / .87$ & $-.52 /-.33$ & $-.02 /-.05$ & $.15 /-.27$ & $.64 / .91$ & $-.72 /-24$ \\
\hline Non-conformism & $-.07 /-.01$ & $.91 /-.93$ & $.17 / .04$ & $.00 / .07$ & $-.14 /-.16$ & $.95 / .93$ & $-.09 / .05$ & $.01 / .11$ \\
\hline Dimension 1 & $.02 /-.01$ & $-.67 / .69$ & $.55 / .61$ & $-.43 /-.28$ & $.08 / .05$ & $-.50 /-71$ & $.58 / .62$ & $-.59 /-.23$ \\
\hline Dime & $-.08 /-.01$ & $.71 /-.82$ & $.53 / .40$ & $-.25 /-.07$ & $-.13 /-.18$ & $.91 / .81$ & $.15 / .44$ & $-.26 / .01$ \\
\hline Prestige & $.08 / .35$ & $.07 / .19$ & $.81 / .32$ & $.49 / .81$ & $.14 / .14$ & $.25 / .-27$ & $.74 / .26$ & $.58 / .90$ \\
\hline
\end{tabular}

Note. Correlations and saturations higher than .40 are given in bold.

When double numbers are presented, the first is from the male subsample and the second from the female subsample.

* CC - genders - are Tucker's coefficients of congruence between best matching factors from the two gender subsamples. The numbers in brackets within each cell represent the best matching factors, where the left one is from the male subsample and the right one from the female subsample. For example (1-1) means that factor number one from the male subsample is best matched by factor number one from the female subsample

** CC -countries - are the Tucker's coefficients of congruence between best matching factors from the same gender subsamples from the two countries. Factor structures of subsamples of the same gender but from the two countries are compared. The numbers in brackets within each cell represent the best matching factor numbers, whereas the left number is from the Macedonian subsample and the right number is from the Croatian subsample. 
Table 7 Unrotated factor structure of Holland's types of vocational interests: factor loadings, percentage of variance explained, factor similarities on gender subsamples and correlations with theoretical dimensions of vocational interests.

\begin{tabular}{|c|c|c|c|c|c|c|}
\hline & \multicolumn{3}{|c|}{$\begin{array}{c}\text { Macedonian sample } \\
\text { (Male/Female loadings) }\end{array}$} & \multicolumn{3}{|c|}{$\begin{array}{c}\text { Croatian sample } \\
\text { (Male/Female loadings) }\end{array}$} \\
\hline & F1 & $\mathrm{F} 2$ & F3 & F1 & $\mathrm{F} 2$ & F3 \\
\hline $\mathrm{R}$ & $.75 / .76$ & $-.28 / .10$ & $-.51 /-.52$ & $.62 / .80$ & $.57 /-.08$ & $.43 /-.50$ \\
\hline I & $.75 / .74$ & $.39 /-.49$ & $-.27 /-.21$ & $.72 / .62$ & $-.39 / .63$ & $.37 /-.14$ \\
\hline A & $.63 / .65$ & $.65 / .-60$ & $-.09 / .05$ & $.51 / .48$ & $-.68 / .74$ & $.23 / .15$ \\
\hline S & $.73 / .73$ & $.19 /-.05$ & $.57 / .59$ & $.73 / .57$ & $-.44 / .04$ & $-.39 / .75$ \\
\hline $\mathrm{E}$ & $.69 / .71$ & $-.34 / .46$ & $.56 / .42$ & $.63 / .59$ & $.28 /-.60$ & $-.68 / .42$ \\
\hline $\mathrm{C}$ & $.75 / .68$ & $-.53 / .58$ & $-.21 /-.31$ & $.57 / .76$ & $.74 / .-45$ & $.10 /-.34$ \\
\hline$\%$ variance explained & $\begin{array}{c}51.59 / \\
50.49\end{array}$ & $\begin{array}{c}17.94 / \\
19.48\end{array}$ & $\begin{array}{c}17.11 / \\
15.62\end{array}$ & $\begin{array}{c}40.22 / \\
41.54\end{array}$ & $\begin{array}{c}29.24 / \\
25.31\end{array}$ & $\begin{array}{c}16.57 / \\
19.11\end{array}$ \\
\hline total & & $\begin{array}{c}86.65 / \\
85.59\end{array}$ & & & $\begin{array}{c}86.02 / \\
85.97\end{array}$ & \\
\hline CC - genders* & $\begin{array}{l}.999 \\
(1-1)\end{array}$ & $\begin{array}{l}-.966 \\
(2-2)\end{array}$ & $\begin{array}{l}.973 \\
(3-3)\end{array}$ & $\begin{array}{r}.978 \\
(1-1)\end{array}$ & $\begin{array}{l}-.806 \\
(2-2)\end{array}$ & $\begin{array}{l}-.786 \\
(3-3)\end{array}$ \\
\hline CC -countries** & $\begin{array}{c}\text { Males } \\
.995 \\
(1-1)\end{array}$ & $\begin{array}{c}\text { Males } \\
-.957 \\
(2-2)\end{array}$ & $\begin{array}{c}\text { Males } \\
-.953 \\
(3-3)\end{array}$ & $\begin{array}{c}\text { Females } \\
.987 \\
(1-1)\end{array}$ & $\begin{array}{c}\text { Females } \\
-.980 \\
(2-2)\end{array}$ & $\begin{array}{c}\text { Females } \\
.985 \\
(3-3)\end{array}$ \\
\hline People - Things & $-.09 / .02$ & $.48 /-.34$ & $.86 / .93$ & $-.00 /-.18$ & $-.80 / .17$ & $-.59 / .96$ \\
\hline Ideas - Data & $.09 / .13$ & $.87 /-.95$ & $-.42 /-.15$ & $.14 / .04$ & $-.80 / .98$ & $.56 /-.01$ \\
\hline Sociability & $-.13 / .08$ & $-.07 / .35$ & $.98 / .91$ & $-.09 /-.18$ & $-.30 /-.52$ & $-.94 / .82$ \\
\hline Non-conformism & $.04 / .12$ & $.97 /-.94$ & $.02 / .22$ & $.11 /-.03$ & $-.96 / .92$ & $.19 / .34$ \\
\hline Dimension 1 & $-.12 / .12$ & $-.57 / .80$ & $.78 / .54$ & $-.14 /-.11$ & $.39 /-.89$ & $-.89 / .40$ \\
\hline Dimension 2 & $-.02 / .08$ & $.86 /-.78$ & $.48 / .59$ & $.06 /-.11$ & $-.97 / .70$ & $-.18 / .69$ \\
\hline Prestige & $.13 / .35$ & $.20 / .10$ & $.38 / .05$ & $.25 / .18$ & $-.20 /-.15$ & $-.06 / 07$ \\
\hline
\end{tabular}

Note. Correlations and saturations higher than .40 are given in bold.

When double numbers are presented, the first is from the male subsample and the second from the female subsample, except for the last row.

* CC - genders - are Tucker's coefficients of congruence between best matching factors from the two gender subsamples. The numbers in brackets within each cell represent the best matching factors, where the left one is from the male subsample and the right one from the female subsample. For example (1-1) means that factor number one from the male subsample is best matched by factor number one from the female subsample

** CC -countries - are the Tucker's coefficients of congruence between best matching factors from the same gender subsamples from the two countries. Factor structures of subsamples of the same gender but from the two countries are compared. The numbers in brackets within each cell represent the best matching factor numbers, whereas the left number is from the Macedonian subsample and the right number is from the Croatian subsample.

\section{DISCUSSION}

If the obtained results are compared to the ones obtained in previous studies, it can be concluded that this study falls in the group of studies confirming both the hexagonal and the spherical model of vocational interests. The obtained measures of fit of the model to the data are in line with those obtained on US samples (Tracey 2002). Apart from that, their numerical values are very similar. 
It can also be noted that the levels of concordance with the model are much higher when only the space of two Prediger's dimensions is considered, i.e. the RIASEC model, than when all three dimensions are taken into account, i.e. when the spherical model is considered. The total level of discrepancy is higher when both the lower and upper prestige types are included than in the case when only the middle level or the level of Holland's types is considered. This is especially pronounced on the Macedonian sample where the relations between types of the hexagonal model, two-dimensional (CIMc_hex $=.96)$ fit the data numerically better than both on the current Croatian sample (CICr_hex $=.89$ ) and Tracey's US samples, while at the same time the level of fit of the spherical model to the data is somewhat lower in the Macedonian sample than in the current Croatian and the US samples $($ CIMc_spher $=.55 ;$ CICr_spher $=.59)$.

Stress decomposition tables obtained in the procedures of multidimensional scaling, which could not be included in this paper due to space limitations, show that contributions of upper and lower Prestige types to the total Stress coefficients are much higher than contributions of the middle Prestige types. A probable explanation for these results could be that they are due to the differences in the cultural and economic systems of both Macedonia and Croatia and the US, where the spherical model originated.

Also, the study confirms the theoretical fundamental structure of vocational interests. In both samples, and also on the gender subsamples, the three-dimensional structure of Tracey's model and the two-dimensional structure of Holland's model were obtained, both preceded by a general factor. In accordance with theoretical expectations, the first extracted factor is a general factor on which all types of vocational interests have high projections, while the other two dimensions are the substantial dimensions of vocational interests. Similar results were obtained in almost all of the previous studies, although the meaning of the general factor has not yet been securely established, given that various authors give different explanations for its existence (e.g. Darcy \& Tracey 2003; Hedrih 2006; Prediger 1982; Rounds \& Tracey 1993; Šverko 2008a; Tracey \& Robbins 2006). It can be noted that a somewhat smaller variability of the general factor is obtained in the Croatian sample (tables 3 and 4).

Substantial fundamental dimensions of vocational interests are identical in both samples, regardless of the model. In both samples the two dimensions extracted from Tracey's and Holland's types correspond to Rounds and Tracey's rotation of Prediger's dimensions (Dimensions 1 and Dimensions 2 created by rotating Prediger's dimensions by 60 degrees), while there was a third dimension of Prestige extracted from Tracey's types (tables 3 and 4). Dimensions obtained in Macedonian and Croatian samples are practically identical and this is confirmed by Tuckers' coefficients of congruence which are all substantially higher than the critical value of .80 (Fulgosi 1988), and almost reach the theoretical maximum value of 1.00 .

Considering the results obtained on the gender subsamples, it can be noted that indicators of fit tend to be somewhat lower when MDS is used on subsamples than on the integral country samples. This may be due to variance of vocational interests being restricted in gender subsamples given the well-known gender differences in vocational interests (e.g. Su, Rounds, \& Armstrong 2009), thus taking away some of the variance included in the model and creating space for various sources of error variance to become larger proportions of the total. Another peculiarity that can be noted with gender subsamples is discrepancies between male and female factor structures on the Croatian sample. Visual inspection of saturations as well as Tucker's coefficients of congruence 
show factors 2 and 3 of RIASEC and factors 3 and 4 of the spherical model to have somewhat different patterns of saturation on the two gender subsamples. On the other hand, inspecting saturation by types, it can be noted that in both of these gender subsamples saturations follow the theoretical propositions - highest saturations with opposite signs are always those on the opposite sides of the theoretical models. This points to the probable explanation for this - due to the exploratory nature of the principal component analysis, and the existing gender differences in expression of certain types of interests, the two PCA procedures produced factors of differing orientations, but still describing the same latent space. As all factor/axes orientations defining the same latent space are equal, this would result in factors assessed as unequal when using saturation-based comparison methods (like Tucker's coefficients), but the structure of the source data being assessed as similar by methods based on correlation structure comparison, such as the methods used for assessing the fit of the vocational interest models to the data. This explanation is supported by the fact that structure of correlations on both these subgroups indeed fit the theoretical models well enough, as can be seen from tables 3 and 4 .

When the results obtained in this study are considered in the broader context of studies of the validity of Holland's and Tracey's models of vocational interests, an interesting tendency can be detected - studies of validity of Holland's model since its conception and up to the end of the 20th century mainly tended to yield results that varied from country to country. A high level of fit was obtained in some countries, while results in other countries showed substantial discrepancies between data and the model, and yet in other countries results completely invalidated the propositions of Holland's model on the structure of relations between vocational interests (Elosua 2007; Farh, Leong \& Law 1998; Leong et al. 1998; Long \& Tracey 2006; Rounds \& Tracey 1996; Ryan, Tracey \& Rounds 1996; Tak 2004). Previous studies mainly used instruments for studying vocational interests based on Holland's theory. On the other hand, studies of the validity of the spherical model have so far produced results confirming the validity of the model, but also of Holland's model tested by using RIASEC measures obtained by using PGI. Apart from differences in the model, it should be noted that most of the studies of validity of Holland's model were conducted in the second half of the 20th century, while studies of validity of the spherical model have all been conducted in the last two decades. If this is taken into account when considering the origin of the obtained differences, it should be acknowledged than one possible reason lies surely with the difference in the model and instruments used to measure it. Holland's model does not include prestige as a dimension, and for this reason, the measures provided by instruments based on it are not balanced for prestige. The spherical model includes this dimension, and for this reason measures of Holland's types obtained by using PGI are obtained strictly by using items describing activities and vocations with the middle prestige level. Therefore, RIASEC measures obtained by using PGI are balanced for prestige.

A second explanation of these differences is based on the time when the studies were conducted - in the second part of the 20th century the world economic system contained many more local specificities and there were much larger differences between economic and education systems of various countries. Social changes and the development of technology, internet and mass communication technologies before all else, created much more uniformity among economical systems of various world countries. Near the end of the 20th century, the communist block ceased to exist. In China, although the communist system was formally preserved, the economy started to function using a model much more similar to the Western economy. The appearance and widespread use of Internet completely 
redefined possibilities for communications across the globe and contributed greatly to the changes in the properties of the world economy. There is an ongoing process of international synchronization of education systems throughout the world, the dominance of international companies is ever more pronounced, and there is a larger number of smaller companies that have almost global reach than was ever the case. All these events contributed to the appearance of the phenomenon known as globalization and this phenomenon also manifests itself as a global process of uniformization of economic and educational systems. Taking this into account, it is completely possible that what the results of studies of validity of vocational interest models actually show is that societies have become more uniform and more similar then they were at the time the first studies of validity of Holland's model were conducted. This explanation is especially supported by the fact that studies conducted in China using Holland-based instruments used to yield varying results, many of which negated the validity of Holland's model on their data, while on the other hand new studies conducted using PGI consistently yielded results confirming the model (Long, Adams \& Tracey 2005). Given this, it might be a good idea for future studies to focus on examining to what extent the obtained differences really are the result of a better model, and to which extent they are simply indicators of globalization at work.

Considering the relevance of these findings for psychological counseling practice, probably the most important find of this paper is that the validity of both Holland's and the spherical model are supported in the population of the Republic of Macedonia. Also, the validity of the Macedonian language version of PGI, created for this study, has been demonstrated, thus adding a new possible tool or set of tools to the inventory of practitioners. The similarity of the results on the Macedonian population to the results obtained in other regional countries can be of use to practitioners working for regional or international companies and/or regional and international markets, because they show that equivalent instruments for measuring vocational interests can be used in various language versions and that sufficient similarity in functioning can be expected.

It should be noted that one limitation of this study is that it was conducted on university students, the majority of which were female. Thus, participants with higher scores on Prestige and on the People side of the People-things dimensions were overrepresented in the sample compared to the general population. Therefore, the generalization of the results to the general population is limited. On the other hand, these two properties tend also to be characteristic of the population seeking career counseling, thus making the results more relevant for this population.

It can be concluded that the obtained results confirm the validity of both spherical and hexagonal models of vocational interests on both Croatian and Macedonian students, although with somewhat higher deviations from the model related to the dimension of Prestige. The results also show the structures of relations between vocational interest types to be very similar in the two national samples and in Macedonian gender samples, while in Croatian gender samples, minor deviations were observed. The results support the validity of the newly created Macedonian language version of the Personal Globe Inventory.

Acknowledgement: The paper is a part of the research done within projects 179002 of the Serbian Ministry of Education, Science and Technological Development and project 1229 supported by the Croatian Science Foundation. 


\section{REFERENCES}

Darcy, Maria, and Terence J. G. Tracey. "Integrating Abilities and Interests in Career Choice: Maximal Versus Typical Assessment.” Journal of Career Assessment 11 (2003): 219-237. doi:10.1177/1069072703251614.

Einarsdóttir, Sif, James Rounds, Stefanía Aegisdóttir, and L. H. Gerstein. "The Structure of Vocational Interests in Iceland: Examining Holland's and Gati's RIASEC Models." Vocational Interests in Iceland EJPA European Journal of Psychological Assessment 18 (2002): 85-95. doi:10.1027//1015-5759.18.1.85.

Elosua, Paula. "Assessing Vocational Interests in the Basque Country Using Paired Comparison Design." Journal of Vocational Behavior 71 (2007): 135-145. doi:10.1016/j.jvb.2007.04.001.

Farh, Jiing-Lih, Frederick T. L. Leong, and Kenneth S. Law. "Cross-Cultural Validity of Holland's Model in Hong Kong." Journal of Vocational Behavior 52 (1998): 425-440.

Fulgosi, Ante. Faktorska Analiza. Zagreb: Školska knjiga, 1988

Hedrih, Vladimir. "Bazična struktura ličnosti i profesionalna interesovanja učenika (Basic Personality Traits and Vocational Interests of High School Students)." University of Belgrade, 2006.

Hedrih, Vladimir. "Structure of Vocational Interests in Serbia: Evaluation of the Spherical Model." Journal of Vocational Behavior 73 (2008): 13-23. doi:10.1016/j.jvb.2007.12.004.

Hedrih, Vladimir, Marina Stošić, Ivana Simić, and Snezhana Ilieva. "Evaluation of the Hexagonal and Spherical Model of Vocational Interests in the Young People in Serbia and Bulgaria." Psihologija 49 (2016): 199210. doi:10.2298/PSI1602199H.

Hedrih, Vladimir, and Iva Šverko. "Evaluation of the Holand Model of the Professional Intersts in Croatia and Serbia.” Psihologija 40 (2007). doi:10.2298/PSI0702227H.

Holland, John L. "A Theory of Vocational Choice.” Journal of Counseling Psychology 6 (1959).

Holland, John L. Self-Directed Search: Assessment Booklet, A Guide to Educational and Career Planning. Odessa: Psychological Assessment Resources, Inc, 1994.

Leong, Frederick T. L., James T. Austin, Uma Sekaran, and Meera Komarraju. "An Evaluation of the CrossCultural Validity of Holland's Theory: Career Choices by Workers in India." Journal of Vocational Behavior 52 (1998): 441-455.

Long, Lirong, Ryan S. Adams, and Terence J. G. Tracey. "Generalizability of Interest Structure to China: Application of the Personal Globe Inventory." Journal of Vocational Behavior 66 (2005): 66-80. doi:10.1016/j.jvb.2003.12.004.

Long, Lirong, and Terence J. G. Tracey. "Structure of RIASEC Scores in China: A Structural Meta-Analysis." Journal of Vocational Behavior 68 (2006): 39-51. doi:10.1016/j.jvb.2005.01.002.

Lorenzo-Seva, Urbano, and Jos M. F. ten Berge. "Tucker's Congruence Coefficient as a Meaningful Index of Factor Similarity." Methodology 2 (2006): 57-64. doi:10.1027/1614-2241.2.2.57.

Darcy, Maria. "Examination of the Structure of Irish Students' Vocational Interests and Competence Perceptions.” Journal of Vocational Behavior 67 (2005): 321-333. doi:10.1016/j.jvb.2004.08.007.

Morgan, Brandon, and Gideon P. De Bruin. "Structural Validity of Holland's Circumplex Model of Vocational Personality Types in Africa." Journal of Career Assessment 26 (2018), 275-290. doi:10.1177/1069072717692747.

Myors, B. "A Simple, Exact Test for the Holland Hexagon." Journal of Vocational Behavior 48 (1996): 339351. doi:10.1006/jvbe.1996.0028.

Prediger, Dale J. "Dimensions Underlying Holland's Hexagon: Missing Link between Interests and Occupations?" Journal of Vocational Behavior 21 (1982): 259-287.

Prediger, Dale J. "Is Interest Profile Level Relevant to Career Counseling?" Journal of Counseling Psychology 45 (1998): 204-211.

Prediger, Dale J., and Kyle B. Swaney. "Work Task Dimensions Underlying the World of Work: Research Results for Diverse Occupational Databases." Journal of Career Assessment 12 (2004): 440-59. doi:10.1177/1069072704267737.

Rounds, James, and Terence J. G. Tracey. "Cross-cultural Structural Equivalence of RIASEC Models and MEasures." Journal of Counseling Psychology 43 (1996): 310-329.

Rounds, James, and Terence J. G. Tracey. "Prediger's Dimensional Representation of Holland's RIASEC Circumplex.” Journal of Applied Psychology 78 (1993): 875-890.

Ryan, Jennifer M., Terence J. G. Tracey, and James Rounds. "Generalizability of Holland's Structure of Vocational Interests Across Ethnicity, Gender, and Socioeconomic Status." Journal of Counseling Psychology 43 (1996). Gottfred-son Hackett \& Watkins Ward \& Bingham: 330-337.

$\mathrm{Su}$, Rong, James Rounds, and Patrick Ian Armstrong. "Men and Things, Women and People: A Meta-Analysis of Sex Differences in Interests.” Psychological Bulletin 135 (2009): 859-884. doi:10.1037/a0017364.

Šverko, Iva. "Struktura profesionalnih interesa u funkciji dobi (Structure of Vocational Interests as a Function of Age)." University of Zagreb, 2002.

Šverko, Iva. "Profesionanlni interesi u funkciji dobi i spola: Evaluacija sfernog modela (Vocational Interests as 
a Function of Age and Gender: Evaluation of the Spherical Model)". University of Zagreb, 2008a.

Šverko, Iva. "Spherical Model of Interests in Croatia." Journal of Vocational Behavior 72 (2008b): 14-24. doi:10.1016/j.jvb.2007.10.001.

Šverko, Iva, and Toni Babarović. "The Validity of Holland's Theory in Croatia.” Journal of Career Assessment 14 (2006): 490-507. doi:10.1177/1069072706288940.

Šverko, Iva, and Toni Babarović. "Integrating Personality and Career Adaptability into Vocational Interest Space.” Journal of Vocational Behavior 94 (2016): 89-103. doi:10.1016/j.jvb.2016.02.017.

Šverko, Iva, and Vladimir Hedrih. "Evaluacija sfernog i heksagonalnog modela strukture interesa u hrvatskim i srpskim uzorcima." Suvremena psihologija 13 (2010): 47-62.

Tak, Jinkook. "Structure of Vocational Interests for Korean College Students." Journal of Career Assessment 12 (2004): 298-311. doi:10.1177/1069072703261555.

Tracey, Terence J. G. "Personal Globe Inventory: Measurement of the Spherical Model of Interests and Competence Beliefs.” Journal of Vocational Behavior 60 (2002): 113-172. doi:https://doi.org/10.1006/jvbe.2001.1817.

Tracey, Terence J. G., and James Rounds. "The Spherical Representation of Vocational Interests." Journal of Vocational Behavior 48 (1996): 3-41. doi: 10.1006/jvbe.1996.0009.

Tracey, Terence J. G. "RANDALL: A Microsoft FORTRAN Program for a Randomization Test of Hypothesized Order Relations." Educational and Psychological Measurement 57 (1997): 164-168.

Tracey, Terence J. G., and Steven B. Robbins. "The Interest-major Congruence and College Success Relation: A Longitudinal Study." Journal of Vocational Behavior 69 (2006): 64-89. doi:10.1016/j.jvb.2005.11.003.

Tracey, Terence J. G. "Analysis of Circumplex Models”. In Handbook of Applied Multivariate Statistics and Mathematical Modeling, edited by H. E. A. Tinsley and S. Brown, 641-664. San Diego, California: Academic Press, 2000.

Tracey, Terence J. G., and James Rounds. "The Arbitrary Nature of Holland's RIASEC Types: A ConcentricCircles Structure.” Journal of Counseling Psychology Rounds \& Tracey Rounds \& Zevon 42 (1995). American Psychological Association: 431-39.

Tracey, Terence J. G., Naotaka Watanabe, and Paul L. Schneider. "Structural Invariance of Vocational Interests Across Japanese and American Cultures.” Journal of Counseling Psychology 44 (1997): 346-354.

\section{STRUKTURA PROFESIONALNIH INTERESOVANJA U MAKEDONIJI I HRVATSKOJ - EVALUACIJA SFERIČNOG MODELA}

Cilj ovog rada je ispitivanje konstruktne validnosti sferičnog $i$ heksagonalnog modela profesionalnih interesovanja. Ovo je ispitivano proverom uklapanja ova dva modela u podatke dobijene na uzorcima studenata iz Republike Makedonije i Republike Hrvatske. Hrvatska $i$ makedonska verzija upitnika profesionalnih interesovanja (Personal Globe Inventory - PGI) zadata je uzorku od 1367 studenata različitih fakulteta iz Hrvatske i Makedonije (737 studenata iz Makedonije i 630 iz Hrvatske). Rezultati su pokazali da i sferični i heksagonalni model odgovaraju podacima bolje od slučaja $i$ da ovi modeli objašnjavaju supstantivni procenat varijanse mera profesionalnih interesovanja. Ispitivanje faktorske structure dobijenih mera profesionalnih interesovanja na ispitivanim uzorcima pokazala je da dobijena struktura generalno odgovara teorijskim očekivanjima. Dobijene dimenzije odgovaraju latentnom prostoru koji je definisaio Predidžer, kao i dimenziji Prestiža iz sferičnog modela.

Ključne reči: profesionalna interesovanja, sferični model, Holandov model, PGI, RIASEC. 